\title{
MENGUNGKAP SISTEM PENGENDALIAN BELIEF SYSTEM PADA UNIVERSITAS YANG BERBASIS ENTREPRENEURSHIP: SEBUAH STUDI FENOMENOLOGI
}

\author{
Wirawan Radianto \\ Universitas Ciputra, UC Town, Citraland, Surabaya 60219, Indonesia \\ E-mail:wirawan@ciputra.ac.id
}

\begin{abstract}
Abstrak
Tujuan dari penelitian ini untuk mengungkap bagaimana dosen memaknai belief systems di Universitas Ciputra. Penelitian ini menggunakan pendekatan kualitatif dengan metode fenomenologi. Data dikumpulkan dengan menggunakan wawancara mendalam dan observasi partisipatif. Keabsahan data penelitian ini menggunakan triangulasi sumber dan metode. Berdasarkan pengalaman para dosen, peneliti menemukan bahwa sistem sosial mampu untuk memotivasi dan mendorong dosen berperilaku sesuai dengan apa yang diharapkan oleh Universitas. Penelitian ini juga menemukan bahwa kreativitas merupakan unsur penting bagi organisasi yang berwawasan entrepreneurship.
\end{abstract}

Kata kunci: Sistem pengendalian manajemen, fenomenologi, perguruan tinggi, kewirausahaan

\begin{abstract}
The purpose of this study was to reveal the meaning of belief system from lecturer perspective in Universitas Ciputra. This research used Phenomenology to uncover phenomena. Two major data collections were indepth interview and participative observation. This research used source and method of triangulation. Based on informant experience, control systems meant social system which could influence subject to act comply with university regulation. This study found that creativity was very important for entrepreneurial organization.
\end{abstract}

Keywords: Management control system, phenomenology, higher education, entrepreneurship

\section{Pendahuluan}

Sistem pengendalian manajemen merupakan salah satu aspek penting dalam setiap organisasi. Merchant and Stedee (2003) menyatakan bahwa sistem pengendalian merupakan sistem yang memastikan bahwa sumber daya organisasi berperilaku sesuai yang diharapkan oleh organisasi. Simons (1990) menyatakan bahwa sistem pengendalian manajemen (SPM) dalam organisasi berfokus pada sumber daya manusia yang menjalankan organisasi, bahkan Simons berpendapat bahwa SPM merupakan aspek penting dalam mendukung strategi perusahaan. Pengelolaan sumber daya manusia tidak dapat dilepaskan dari SPM. Dalam fungsi manajerial, SPM pada awalnya lebih difokuskan pada fungsi evaluasi dibandingkan fungsi perencanaan dan implementasi, namun pada perkembangannya saat ini, SPM mencakup proses perencanaan sampai dengan monitoring dan evaluasi baik jangka panjang maupun jangka pendek.

Aspek sumber daya manusia merupakan aspek yang sangat penting dalam setiap organisasi karena sumber daya manusia, dikenal dengan human capital, berperan besar sebagai sumber inovasi bagi setiap organisasi. Terlebih lagi dalam organisasi yang merupakan knowledge intensive firms yaitu organisasi yang memiliki proporsi intellectual capital yang besar, maka akan bergantung pada kualitas intangible assets yang dimiliki oleh organisasi tersebut. Salah satu sistem yang ditujukan untuk mengelola sumber daya manusia adalah SPM.

Perguruan tinggi adalah salah satu contoh dari knowledge intensive firm sehingga human capital memiliki peran yang lebih besar dibandingkan dengan tangible asset. Ballow et al. (2004) (dalam Petty \& Guthrie, 2000) menemukan bahwa knowledge intensive firms hanya memiliki tangible asset antara $15 \%$ sampai $25 \%$, selebihnya adalah intangible assets. Beberapa penelitian menemukan bahwa human capital adalah aspek yang sangat penting dan memiliki pengaruh yang signifikan terhadap kinerja organisasi (Zhang, Zhu, \& Kong, 2006; Wang, 2008; Tan, Plowman, \& Hancock, 2007; Ulum, Ghozali, \& Chariri, 2008; Ulum, 2009; Solikhah, Rohman, \& Meiranto, 2010; Yuniasih, Wirama, \& Badera, 2010). 
Kaplan and Norton (2004), Petty and Guthrie (2000) menyatakan bahwa human capital merupakan faktor yang sangat penting dalam menghasilkan competitive advantage dan meningkatkan kinerja organisasi. Hal ini merujuk bahwa human capital, merupakan sumber utama organisasi untuk bergerak menuju pencapaian visi organisasi. Oleh karena itu, dosen merupakan faktor sangat penting dalam keunggulan bersaing (competitive advantage) bagi setiap perguruan tinggi.

Saat ini, peran human capital sebagai dasar keunggulan bersaing perguruan tinggi menjadi sedemikian penting, karena persaingan antar perguruan tinggi begitu meningkat. Dampak dari persaingan tersebut begitu terasa dan dapat dibuktikan dengan banyaknya dampak yang muncul seperti merger perguruan tinggi, akuisisi perguruan tinggi, penutupan perguruan tinggi, munculnya perguruan tinggi baru, dan masuknya perguruan tinggi asing dalam berbagai bentuk. Oleh karena itu, kesiapan sumber daya manusia, terutama dosen merupakan aspek yang sangat penting bagi perguruan tinggi. Dosen harus mampu menjalankan fungsinya yaitu tri dharma perguruan tinggi dan mampu untuk menjalankan tugas lain yang dibebankan kepadanya. Secara singkat, dosen harus berperilaku sesuai yang diharapkan oleh perguruan tinggi yang bersangkutan.

Salah satu alat untuk memastikan para dosen berperilaku sesuai dengan yang diharapkan oleh organisasinya adalah SPM. Saat ini, sudah banyak perguruan tinggi yang menerapkan sistem pengendalian, seperti misalnya presensi untuk dosen dan staf, sistem mengukur kinerja dosen, sistem penghargaan, dan pembentukan budaya organisasi. Namun demikian, penelitian mengenai penerapan SPM di perguruan tinggi masih sangat sedikit. Terlebih lagi penelitian yang menginvestigasi bagaimana pelaku sistem memaknai sistem yang berlaku di perguruan tinggi masih belum pernah dilakukan. Penelitian ini memulai untuk menginvestigasi SPM bukan dari sudut pandang pengambil keputusan atau perancang sistem tersebut, namun dilihat dari sudut pandang pelaku sistem tersebut. Ketika diketahui bagaimana pelaku memaknai sistem pengendalian tersebut, maka pihak pembuat kebijakan di universitas akan dapat merancang sistem pengendalian yang efektif.

Tujuan penelitian ini adalah untuk mengungkap bagaimana dosen memaknai sistem pengendalian yang diterapkan, secara khusus beliefs systems (Simons, 1995). Beliefs systems merupakan salah satu aspek pengendalian informal yang mendukung pengendalian formal. Penelitian ini menginvestigasi secara mendalam bagaimana pengalaman pelaku sistem, dalam penerapan beliefs systems.
Penelitian ini tidak bertujuan untuk mengkonfirmasi teori atau penelitian sebelumnya, juga bukan untuk tujuan generalisasi. Oleh karena itu, tinjauan teoritis dalam penelitian ini tidak digunakan untuk mengkonfirmasi temuan dengan teori yang sudah ada, namun lebih bertujuan untuk memastikan bahwa proses penelitian tidak menyimpang dari masalah yang akan diteliti atau melebar ke isu penelitian lainnya. Penelitian ini mengenai SPM, sehingga tinjauan literatur yang dilakukan berhubungan dengan konsep SPM secara khusus beliefs systems (Simons, 1990).

Sistem Pengendalian Manajemen (SPM) adalah sistem untuk memastikan bahwa seluruh elemen organisasi mencapai goal congruence. SPM adalah sistem yang memastikan bahwa sumber daya manusia melakukan apa yang diharapkan organisasi. SPM adalah sistem yang mendukung pengambilan keputusan manajemen (Chenhall, 2003; Merchant \& Steede, 2003; Anthony \& Young, 2003; Horngren, Sundem, \& Stratton, 2005; Anthony \& Govindarajan, 2007). Simons (1990) menggolongkan SPM menjadi empat aspek yang dikenal dengan four levers of control, yaitu beliefs systems, boundary systems, serta feedback and measurement system. Penelitian ini secara khusus membahas mengenai beliefs systems sehingga bagian selanjutnya akan menyajikan tinjauan teoritis dari aspek pengendalian tersebut.

Beliefs systems merupakan nilai-nilai organisasi dan arah organisasi akan menuju ke mana (Kimura \& Mourdoukourtas, 2000). Sistem ini digunakan untuk menginspirasi dan mengarahkan karyawan untuk menemukan kesempatan-kesempatan yang ada, mengarahkan karyawan untuk mencari ide-ide baru, memberikan nilai-nilai dasar organisasi, serta memberikan tujuan dan arah organisasi (Wongkaew, 2013; Hoque \& Chia, 2012). Oleh karena itu, sistem pengendalian ini bertujuan untuk memotivasi individu supaya individu tersebut berperilaku sesuai yang tujuan organisasi. Beliefs systems dimaksudkan untuk mengkomunikasikan misi, kredo, dan tujuan organisasi yang semuanya ini membantu manajer untuk mentransformasi nilai-nilai yang sekiranya masih sulit untuk dipahami karyawan sekaligus menjadikannya aktivitas yang fokus pada tujuan organisasi (Bruining, Bonnet, \& Wright, 2004). Melalui sistem ini, pemimpin akan dapat menginspirasi karyawan sekaligus mengendalikan karyawannya supaya tidak berperilaku oportunistik (Ismail, 2013; Hoque \& Chia, 2012). Ouchi (1979) berpendapat bahwa beliefs systems dan budaya organisasi adalah termasuk dalam sistem pengendalian informal.

Sejauh yang diketahui, sampai saat ini penelitian yang secara khusus hanya meneliti mengenai beliefs systems secara khusus belum pernah dilakukan, 
namun penelitian mengenai level of control secara keseluruhan mencakup beliefs systems, diagnostic system, interactive system, dan boundary sistems dilakukan. Namun demikian, penelitian sebelumnya mengenai beliefs systems yang merupakan satu kesatuan dari sistem pengendalian manajemen sudah dilakukan. Davila (2000) menyatakan bahwa SPM memiliki peran yang penting dalam pengembangan inovasi produk baru melalui informal control dari model Simons. SPM juga digunakan oleh manajer untuk memperoleh informasi yang berguna dalam rangka mengurangi ketidakpastian. Tahun 2009, penelitian kembali dilakukan mengenai SPM dan menemukan bahwa SPM memiliki peran tidak hanya mengembangkan inovasi tetapi juga mendorong inovasi (Davila, Foster, \& Li, 2009). Penelitian ini menemukan bahwa dialog antara staf dan pimpinan akan menghasilkan ide-ide baru. Kimura and Mourdoukoutas (2000) dalam penelitiannya menemukan bahwa SPM yang efektif adalah SPM yang mampu mengintegrasikan elemen sistem pengendalian untuk meningkatkan efektivitas operasional, kreativitas individu, dan kemampuan bersaing perusahaan. Mereka berpendapat agar SPM efektif maka harus diterapkan secara holistik yang mencakup diagnostic system systems yang dilengkapi dengan boundary control, interactive control, dan beliefs systems. Herbert (2009) mengeksplorasi implikasi SPM terhadap pemberdayaan sumber daya manusia. Penelitian ini menemukan bagaimana konsep SPM dari Simons mampu untuk memberdayakan individu. Bruining et al. (2004) melakukan penelitian mengenai peran SPM pada situasi buy-out. Hasil penelitian menemukan bahwa beliefs systems dan interaction control berperan penting dalam proses buy-out namun kedua sistem pengendalian tersebut tetap tidak dapat menggantikan diagnostic control. Henri (2006) dalam penelitiannya menemukan bahwa penggunaan SPM secara interaktif akan mendorong kapabilitas organisasi. Hasil penelitian ini mendukung sistem pengendalian dari model Simons sebagai alat mendukung implementasi dari strategi yang diharapkan organisasi, tetapi juga sebagai alat untuk mendorong penemuan strategi baru. Beberapa penelitian menemukan budaya organisasi yang merupakan informal control berhubungan dengan SPM (Morsing \& Oswald, 2009; Vosselman \& Kooistra, 2009; Efferin \& Hopper, 2007; Kahar, Triyuwono, Irianto, \& Ludigdo, 2013; Wahyudi, 2008). Beberapa penelitian terdahulu ini menunjukkan bahwa konsep SPM sudah berkembang sedemikian pesat. Dahulu fokus ke pengukuran kinerja, namun sekarang sudah mencakup pengelolaan sumber daya manusia, strategi, bahkan inovasi di organisasi.

\section{Metode Penelitian}

Penelitian ini menggunakan metode fenomenologi karena bertujuan untuk memahami dan memaknai fenomena tentang apa yang dialami oleh subjek penelitian suatu konteks khusus yang alamiah (Moleong, 2008), dalam hal ini adalah beliefs systems. Oleh karena itu, metode ini tepat diterapkan dalam penelitian ini karena akan mampu mengungkap pengalaman secara nyata objek penelitian dalam konteks penerapan belief system yang sesungguhnya.

Penelitian ini dilakukan dengan strategi single case study. Melalui strategi ini, maka hasil penelitian akan lebih mendalam dan komprehensif serta sesuai dengan kondisi yang ada di tempat penelitian. Oleh karena itu, dipilihlah tempat penelitian di Universitas Ciputra (UC) Surabaya. Tempat penelitian ini dipilih karena memiliki karakteristik yang unik yaitu universitas yang dikelola secara entrepreneurial. Penelitian ini dapat memberi kontribusi bagaimana beliefs systems yang ada di universitas yang bercirikan entrepreneurship. Unit analisis penelitian ini adalah dosen dengan beberapa kriteria yaitu informan harus sudah bekerja di UC minimal lebih dari satu tahun. Informan harus aktif dalam membimbing proyek mahasiswa karena proyek bisnis mahasiswa adalah tugas yang sangat penting di Universitas Ciputra. Informan juga harus menyediakan waktu dan bersedia untuk diwawancarai. Dosen yang diambil sebagai informan berasal dari enam program studi yang ada di UC.

Agar penelitian ini teruji kualitasnya, maka peneliti menggunakan empat kriteria keabsahan data penelitian kualitatif yaitu credibility, transferability, dependability, dan confirmability (Kuswarno, 2009; Wahyuni, 2012; Ghony \& Almanshur, 2012; Emzir, 2010). Dalam melakukan pengujian credibility, peneliti menggunakan triangulasi sumber dan metode (Kuswarno, 2009; Sugiyono, 2012; Emzir, 2010; Creswell, 2009). Dalam memperkuat kredibilitas penelitian, peneliti menggunakan prolonged engagement (Wahyuni, 2012; Creswell, 2009). Pengujian transferability dilakukan dengan cara peneliti secara sistematis dan berhati-hati menuliskan secara rinci bagaimana proses penelitian ini dilakukan. Uji dependability dilakukan bersamaan dengan pengujian confirmability yaitu mematuhi sistematika dan proses yang didiskusikan dengan pakar.

Dua metode pengumpulan data dilakukan melalui wawancara mendalam dan observasi partisipatif. Wawancara mendalam digunakan untuk mengungkap pendapat informan yang tidak bisa terungkap melalui observasi. Observasi partisipatif bertujuan untuk mengamati perilaku informan sehari-hari ber- 
samaan dengan wawancara informan. Teknik analisis data yang digunakan yakni fenemonologi yaitu teknik untuk menangkap kebenaran dari teks (beliefs systems), sebagaimana adanya dari informan berdasarkan pengalaman mereka dan menginterpretasi hasil wawancara dan observasi yang dilakukan. Selanjutnya, hasil penafsiran informan dianalisis dengan menggunakan metode analisis StevickColaizzi-Keen (Sudarma, 2013; Hycner, 1985). Metode ini adalah yang paling tepat dilakukan karena merupakan metode yang sistematis, sehingga mampu menerapkan urutan logis dalam menganalisis data mentah dari lapangan. Metode ini dapat menghasilkan gabungan lengkap dari proses teksturisasi yang selanjutnya menghasilkan deskripsi struktural yang merupakan tema penting. Metode ini mampu untuk membimbing secara detail dan tahapan yang jelas mengenai proses penelitian sampai dengan tahapan sintesis dan kesimpulan.

\section{Hasil Penelitian dan Pembahasan}

Penelitian ini berhasil mewawancarai 18 informan dengan berbagai latar belakang pendidikan dan pengalaman. Penelitian ini menggunakan alat audio untuk merekam wawancara. Setelah wawancara dilakukan, maka dibuatlah transkrip wawancara yang selanjutnya merupakan bahan mentah yang digunakan untuk analisis data. Apabila peneliti membutuhkan data tambahan atau ada hal-hal yang kurang dipahami, maka peneliti kembali melakukan wawancara dengan informan-informan tersebut. Namun demikian, dari beberapa informan yang sudah direncanakan akan diwawancarai ternyata ada beberapa informan tidak berhasil diwawancarai karena alasan kesibukan dan sakit. Rata-rata wawancara dilakukan sekitar empat puluh lima menit sampai dengan satu jam untuk setiap informan, tidak termasuk wawancara informal yang telah dilakukan. Penelitian lapangan yang dilakukan membutuhkan waktu sekitar satu tahun, dan wawancara dilakukan selama kurang lebih empat bulan.

Faktor hubungan antar dosen dan hubungan antara dosen dan pimpinan merupakan aspek penting dalam organisasi. Hubungan interpersonal yang baik akan berdampak pada munculnya kondisi kerja yang kondusif untuk para dosen dalam bekerja. Faktor lingkungan kerja yang kondusif merupakan aspek yang sangat penting untuk memotivasi para dosen. Manusia sebagai makhluk sosial tidak lepas dari saling keterkaitan dalam memenuhi kebutuhannya. Kebutuhan untuk dibantu dan membantu, diperhatikan dan memperhatikan, dan hubungan timbal balik lainnya menjadi faktor pendorong informan saling bekerja sama membentuk iklim budaya organisasi yang khas. Pengalaman informan menyatakan bahwa hubungan saling menolong, menghargai, dan hubungan baik lainnya merupakan faktor penting dosen bekerja dengan baik. Salah seorang informan menyatakan:

"Penghargaan itu juga mungkin bukan hanya berdasarkan reward berdasarkan apa nominal tapi penghargaan bisa dari orang-orang sekitarnya bisa dari dia sendiri juga karena kita ketika dihargai sama orang-orang sekitar kita pun kita tahu bahwa kita bernilai kita berharga itu akan lebih."

Penghargaan merupakan salah satu kebutuhan manusia di samping kebutuhan primer lainnya. Melalui hubungan yang saling menghargai baik menghargai pekerjaan yang dilakukan ataupun individu yang melakukannya, maka situasi kondusif muncul yang berdampak pada munculnya motivasi individu. Penghargaan dimaknai tidak hanya unsur reward tetapi bagaimana pimpinan mampu untuk menciptakan iklim bekerja yang kondusif. Selain itu, informan yang merasa memiliki "value" merupakan faktor penting untuk meningkatkan semangat bekerja dan mengubah perilaku informan tersebut maupun informan lainnya. Pendapat informan tersebut didukung oleh informan lainnya seperti berikut: "Adanya kesempatan, adanya penghargaan, adanya motivasi, adanya perhatian dan tentu saja yang lain adalah reward secara financial ... juga support dari teman teman". Pendapat informan tersebut memberikan tekanan yang menarik yaitu "support dari teman-teman". Pengalaman ini dapat diinterpretasikan bahwa informan sebagai dosen tidak dapat bekerja sendiri namun bergantung pada orang lain. Hubungan interpersonal yang baik sudah menjadi faktor penting dan faktor yang harus ada di Universitas Ciputra. Pengalaman informan ternyata memiliki keterkaitan dengan apa yang berusaha dibangun oleh pihak Manajemen Universitas Ciputra. Manajemen tidak hanya mengembangkan budaya organisasi yang hanya mencakup value of entrepreneurship spirit, namun juga hubungan antar manusia seperti yang diungkapkannya: "Kemudian apa interrelasi antar manusianya, karena itu akan menjadi sumbernya juga daripada beberapa hal-hal yang ini kan tetapi di samping menjadi sumberdaya juga sumber kekuatan".

Penelitian ini mengungkap bagaimana dosen mampu dimotivasi tidak hanya oleh reward system seperti gaji yang tinggi, tunjangan-tunjangan, dan benefit yang lain. Terungkap bahwa faktor informal menjadi hal yang sangat penting bagi dosen untuk 
mampu bekerja dengan optimal. Faktor kenyamanan dalam bekerja mempengaruhi dosen untuk berperilaku menjadi lebih baik. Tidak hanya perilaku keseharian namun juga perilaku untuk mampu mencapai target-target yang ditetapkan. Sebagai contoh, seorang informan yang sebelumnya sangat minim membuat karya tulis ilmiah dan informan lainnya yang belum pernah sama sekali membuat karya tulis ilmiah. Tahun 2013 mampu membuat lebih dari satu karya ilmiah dan dipresentasikan di Seminar Nasional menyatakan: "Kalau sistem pengendaliannya tidak disertai dengan budaya yang kondusif ya orang tidak akan enjoy, orang hanya akan merasa bahwa sistem ini mengekang". Budaya yang kondusif akan mendorong informan menikmati pekerjaannya, namun sistem yang mengekang akan membuat informan tidak merasa nyaman bekerja. Pendapat informan tersebut didukung oleh informan lain yang merupakan informan yang cukup senior sebagai berikut: "Kalau yang memotivasi sebenernya kondisi kerja". Informan tersebut menyatakan dalam wawancara informal bagaimana dia mampu bekerja dengan lebih menyenangkan ketika hubungan antar dosen dan hubungan antar dosen dan Ketua program studi (Kaprogdi) berjalan dengan baik. Kondisi ini ternyata mampu memotivasi para dosen untuk bekerja.

Informan lain menyatakan bahwa lingkungan yang kondusif tidak hanya suasananya saja, namun dampak dari suasana yang diciptakannya. Salah satu faktor positif dari hubungan yang baik adalah adanya teladan dari kolega atau pimpinannya. Informan menyatakan: "Katakanlah ketika kita bergaul, kita ada di lingkungan yang kondusif dan kita berada di tengahtengah orang yang mempunyai teladan yang baik, kita itu secara tidak langsung akan berbuat baik". Pendapat informan tersebut mengungkap bagaimana lingkungan yang kondusif adalah lingkungan yang diciptakan, bukan lingkungan yang secara tiba-tiba muncul. Lingkungan kondusif akan dibentuk oleh pemimpin yang mengelola organisasi tersebut. Ketika pemimpin mampu memberikan teladan yang baik, maka budaya untuk bekerja yang baik juga akan muncul dengan sendirinya. Ketika informan sudah meneladani pimpinannya atau pemimpin sudah mampu untuk menginspirasi para informan melalui keteladanan, maka organisasi akan berjalan sesuai dengan yang direncanakan. Semua pihak yang berperan penting dalam organisasi akan berjalan sesuai dengan apa yang sudah ditetapkan. Hal ini mampu untuk menginternalisasi visi dan misi program studi bahkan visi dan misi dari universitas. Pemimpin akan mampu tidak hanya mengkoordinasi sumber daya manusianya, namun juga akan mampu untuk mengelola dengan baik sumber daya manusia yang merupakan faktor penting dalam Universitas. Keteladanan akan memunculkan transfer tacit knowledge, sehingga memungkinkan untuk mengembangkan dosen-dosen lain. Keteladanan akan meningkatkan loyalitas dari staf dan meningkatkan "trust" karena adanya unsur integritas antara apa yang diucapkan dengan apa yang dilakukan.

Pengalaman informan-informan lainnya menunjukkan bahwa lingkungan kerja yang memungkinkan para informan berpartisipasi dalam aktivitas yang diadakan akan memotivasi mereka untuk bekerja sesuai dengan yang sudah direncanakan. Mereka akan bertanggungjawab atas apa yang telah dianggapnya sebagai "kontrak" kerja ketika mereka dan pimpinan bersama-sama menyepakati tugas dan kewajibannya: "Dan saya ikut terlibat di dalam menyepakati tugas tersebut, maka saya juga harus bertanggungjawab dan ... menjalankan itu". Demikian juga dengan informan lainnya yang menyatakan hal yang sama: “... saya merasa itu diberikan tanggung jawab pak. Karena ada tanggung jawab seperti itu otomatis saya harus menyelesaikan". Pendapat informan tersebut mendukung konsep dari partisipasi anggaran yang merupakan salah satu konsep penting dalam bidang akuntansi manajemen. Konsep tersebut menyatakan bahwa manajer atau individu akan meningkat kinerjanya ketika mereka dilibatkan dalam penyusunan anggaran maupun target-target individu atau organisasi. Melalui kerjasama antara pimpinan dan bawahan, maka target yang ditetapkan akan terukur, sehingga hal ini akan memotivasi individu untuk bekerja sesuai dengan target yang sama-sama ditentukan. Konsep ini berhubungan dengan kondisi yang kondusif karena pimpinan memberikan kesempatan kepada informan untuk ikut berperan dalam pencapaian tujuan organisasi. Konsep penghargaan nampak muncul dalam konsep ini karena melalui partisipasi, maka pihak pimpinan akan menghargai pendapat informan. Upaya untuk mengembangkan iklim partisipatif nampaknya menjadi faktor yang sangat penting untuk meningkatkan kinerja para informan.

Temuan lain yang menarik adalah kondisi kerja yang kondusif ternyata dimaknai berbeda oleh informan lainnya. Informan tersebut menyatakan bahwa kondisi kerja yang kondusif tidak hanya berbicara masalah hubungan yang baik. Namun lebih dari itu yang bersangkutan menyatakan bahwa kondisi yang nyaman itu adalah tersedianya ruang yang cukup untuk "bergerak" seperti yang diungkapkannya. Informan tersebut menyatakan "Menciptakan lingkungan dan suasana yang nyaman ... Nyaman itu yah gini ... ada ruang yang cukup buat kita untuk bergerak, untuk bermanuver tentunya dalam, dalam koridor-koridor yang ada". 
Melalui beberapa wawancara informal baik pada saat makan siang, rapat, maupun aktivitas lainnya, peneliti menemukan bahwa aktualisasi diri perlu untuk diberikan ruang kepada para informan. Ungkapan informan tersebut menyatakan bahwa sesungguhnya mereka perlu ruang untuk menuangkan ide kreatif dan inovatif mereka. Konsep ini sangat menarik karena diungkapkan oleh para dosen yang bekerja di universitas yang memiliki budaya entrepreneurship. Hal ini merupakan cerminan bagaimana iklim budaya entrepreneurship yang dikembangkan oleh universitas mampu untuk mempengaruhi para dosen dalam berpikir dan bertindak kreatif. Hal ini menyebabkan konstruksi yang ada dalam benak mereka bahwa ruang gerak untuk mengeluarkan ide-ide merupakan bagian dari lingkungan yang kondusif. Hal yang diungkapkan oleh informan tersebut sebenarnya sejalan dengan yang diinginkan oleh para pimpinan. Salah seorang pimpinan menyatakan bahwa Manajemen Universitas Ciputra secara terencana memang mengembangkan nilai-nilai spirit of entrepreneurship sebagai budaya di Universitas Ciputra. Beliau juga menambahkan "memberikan kesempatan kepada setiap staff itu untuk mengembangkan entrepreneurship-nya sesuai dengan visi". Hal ini menjadi salah satu temuan penting dalam penelitian ini, yaitu pengembangan kreativitas dosen menjadi salah satu faktor penting untuk memotivasi dosen di Universitas Ciputra.

Berdasarkan pengalaman para dosen dalam penelitian ini, maka berhasil diungkap beberapa aspek penting. Pertama, para dosen merasa termotivasi ketika mereka memiliki hubungan yang baik dengan koleganya. Hubungan yang baik antar individu, baik hubungan antara dosen dengan dosen, dosen dengan mahasiswa, dan dosen dengan staf non akademik. Hal -hal tersebut merupakan aspek yang penting untuk memunculkan lingkungan pekerjaan yang kondusif. Hubungan yang membangun dan menyenangkan akan mempengaruhi dosen, sehingga dia akan akan menikmati pekerjaannya. Seperti pernyataan seorang informan saat peneliti melakukan wawancara informal "Seberat apapun pekerjaan kita di kantor tapi kalau punya teman-teman yang sangat mendukung dan peduli rasanya saya betah kerja di sini". Hubungan saling menolong, menghargai, dan hubungan baik lainnya merupakan faktor penting dosen bekerja dengan baik. Aspek ini merupakan salah satu ciri dari perguruan tinggi yaitu kolegialisme. Salah satu kontribusi yang penting dari konsep beliefs systems dari Simons (1990) dalam ranah perguruan tinggi adalah model Simons dapat diterapkan pada dua pendekatan organisasi yang berbeda yaitu organisasi yang menganut kolegialism dan managerialism. Hasil ini mem- perkuat konsep Simons bahwa konsep ini dapat diterapkan di perguruan tinggi.

Kedua, faktor penghargaan memegang peranan yang sangat penting dalam memotivasi dosen. Melalui penghargaan baik dari pimpinan maupun dari koleganya mereka merasa bahwa mereka memiliki nilai, dalam hal ini nilai tersebut akan memberikan kepada mereka kebanggaan bahwa mereka layak dihargai oleh orang lain. Faktor penghargaan berdasarkan pengalaman informan seringkali menjadi faktor yang begitu penting dibandingkan reward dalam bentuk finansial. Faktor penghargaan selalu ditemukan di organisasi berorientasi laba, sehingga merupakan organisasi yang menggunakan pendekatan managerialsm. Konsep managerialism adalah konsep meritokrasi yaitu konsep penghargaan diberikan kepada pihak yang berprestasi. Penelitian ini memberi sumbangan bagaimana konsep SPM Simons terutama beliefs systems dapat digunakan di perguruan tinggi yang memakai konsep managerialism dan kolegialism. Perguruan tinggi merupakan lembaga yang saat ini bergesar dari konsep kolegialisme ke managerialisme (Winston, 1999; Hanna, 1998; Marginson, 2004). Penelitian ini menguatkan bahwa konsep Simons (1990) dapat diterapkan di perguruan tinggi.

Ketiga, adanya partisipasi dari dosen dalam proses penentuan arah dan tujuan organisasi serta target yang harus dicapai. Partisipasi aktif ini ternyata mampu untuk mempengaruhi perilaku dosen dalam menyelesaikan pekerjaannya. Konsep ini pimpinan melihat dosen sebagai bagian dari komunitas sosial mereka, sehingga tujuan dari komunitas tersebut harus dirumuskan secara bersama-sama. Lingkungan kerja yang memberikan kesempatan serta memungkinkan para dosen berpartisipasi dalam perencanaan dan penetapan target akan memotivasi mereka untuk bekerja sesuai dengan yang sudah direncanakan. Mereka akan bertanggungjawab atas apa yang telah dianggapnya sebagai "kontrak" kerja ketika mereka dan pimpinan bersama-sama menyepakati tugas dan kewajibannya.

Keempat, aspek keteladanan baik itu dari rekan sekerja maupun pimpinan menjadi faktor penting bagi informan dalam bekerja. Lingkungan yang kondusif menurut beberapa informan adalah adanya iklim keteladanan, sehingga melalui keteladanan dapat memberikan arah bagaimana informan semestinya berperilaku, terutama bagi informan yang masih tergolong dosen junior. Aspek keteladanan begitu penting karena mempengaruhi karakter informan. Melalui keteladanan, informan memahami apa yang dapat mereka kerjakan dan apa yang tidak boleh mereka kerjakan. Keteladanan juga dapat mendukung upaya pembentukan iklim budaya organisasi yang diharapkan oleh organisasi. 
Kelima, lingkungan yang kondusif adalah lingkungan yang mampu memberikan ruang bagi para dosen untuk mengembangkan kreativitas. Konsep ini merupakan konsep bagaimana informan diberikan fasilitas untuk mengaktualisasikan dirinya sesuai dengan apa yang diharapkan namun tetap sesuai dengan aturan atau koridor yang ada. Semakin informan bisa berkembang dan diizinkan berkembang, maka semakin dia mampu untuk meningkatkan kinerjanya yang pada akhirnya akan meningkatkan kinerja organisasi. Dua temuan yang terakhir ini sangat menarik karena belum pernah sebelumnya dua hal ini menjadi konsep kondisi yang kondusif di sebuah organisasi. Aspek kelima ini merupakan bukti bahwa Universitas Ciputra merupakan universitas yang memiliki budaya entrepreneurship di dalamnya yang mampu mendorong setiap civitas akademika untuk berperilaku seperti entrepreneur.

Temuan-temuan tersebut membuat peneliti mendeskripsikan struktur dari analisis sebelumnya yang mencakup bagaimana informan termotivasi dan mampu berperilaku tertentu karena mereka memiliki hubungan yang baik dengan koleganya, mengalami penghargaan, adanya partisipasi dari dosen dalam proses penentuan arah dan tujuan organisasi serta target yang harus dicapai, adanya keteladanan, dan adanya lingkungan yang mampu memberikan ruang bagi para dosen untuk mengembangkan kreativitas. Kelima temuan yang muncul tersebut digabungkan oleh peneliti menjadi bentuk sistem pengendalian yang berdasarkan sistem sosial.

Bentuk sistem pengendalian sistem sosial adalah bagaimana lingkungan bekerja yang kondusif dapat memotivasi dan mengelola perilaku dosen. Sistem pengendalian sosial adalah sistem yang mempengaruhi perilaku individu, sehingga individu tersebut berperilaku sesuai yang diharapkan oleh organisasi melalui lingkungan sosial di mana dia berada. Sistem ini mencakup bagaimana hubungan dosen dengan koleganya dan kondisi lingkungan tempat kerjanya. Kondisi lingkungan pekerjaan yang nyaman dan kondusif akan mempengaruhi secara positif perilaku para dosen, sehingga mereka akan termotivasi untuk bekerja dengan optimal dan berusaha mencapai tujuan organisasi.

Peneliti mengingat sebuah peristiwa pada tahun 2008, saat itu ada seorang dosen yang sharing kepada peneliti mengenai pekerjaannya. Dia merasa bahwa di UC pekerjaannya sangat berat, berbeda dengan perguruan tinggi lain. Dia merasa tertekan dan seringkali tidak sanggup untuk menjadi dosen yang mampu melakukan "multi tasking". UC memberikan targettarget yang berasal dari dekan yang harus dipenuhi. Dia bahkan merasa sangat tidak nyaman ketika diberikan tugas mengajar mata kuliah yang bukan merupakan keahliannya. Peneliti masih ingat perbincangan ini dilakukan di warung makan ketika kami sedang makan bersama-sama. Peneliti memang melihat wajahnya begitu loyo dan tidak bersemangat, seakan-akan dia terlihat sudah sangat kelelahan dan tertekan. Peneliti mengajukan pertanyaan mengapa tidak mengundurkan diri saja dan mencari universitas lainnya. Saat itu yang bersangkutan menjawab "yang membuat saya betah di sini ya teman-teman, saya melihat teman-teman sangat kompak dan rukun. Saya tidak yakin bisa menemukan hal ini di tempat lain". Selanjutnya, dia mengakhiri perbincangan dengan mengatakan "jujur ya pak, yang membuat saya tidak pindah kerjaan karena kondisi lingkungan yang kondusif dan teman-teman yang sudah seperti saudara". Pengalaman ini merupakan salah satu bukti bahwa sistem pengendalian sosial memiliki peran penting untuk mempengaruhi perilaku dosen. Temuan ini juga membuktikan bahwa sistem pengendalian informal kerap kali menjadi lebih penting dan efektif dibandingkan dengan sistem pengendalian formal. Penemuan ini memperkuat apa yang sudah diteliti sebelumnya bahwa sistem pengendalian informal ternyata lebih baik dibandingkan dengan sistem pengendalian akuntansi. Oleh karena itu, sebaiknya universitas menggunakan sistem pengendalian informal dan mengutamakan hubungan antar personal.

Sistem sosial yang ditemukan di Universitas Ciputra merupakan nilai organisasi yang khas. Schein (2004) dalam Morsing and Oswald (2009) menyatakan bahwa salah satu elemen paling penting dari organisasi yang maju adalah pengetahuan dan pemahamannya tentang nilai-nilai organisasi oleh anggota organisasi. Hasil penelitian ini memperkuat penelitianpenelitian sebelumnya terutama penelitian Davila (2000) yang menyatakan bahwa SPM mampu mendorong inovasi. Melalui kreativitas yang muncul sebagai respon dari SPM yang diterapkan, maka mampu untuk mendorong munculnya inovasi. Penelitian ini juga mendukung konsep dari Merchant and Steede (2003), Anthony and Young (2003), Horngren et al. (2005), dan Anthony and Govindarajan (2007) yang menyatakan bahwa ada hubungan antara SPM dan sumber daya manusia. Penelitian ini menemukan bahwa beliefs systems akan mampu untuk memotivasi sumber daya manusia. Hasil penelitian ini mendukung penelitian sebelumnya yang dilakukan oleh Wongkaew (2013) serta Hoque and Chia (2012).

Penelitian ini sangat penting bagi peningkatan kinerja perguruan tinggi. Melalui pengendalian manajemen yang tepat, dalam kasus ini adalah beliefs systems, maka perguruan tinggi dapat mengembangkan aset yang paling berharga yaitu sumber daya 
manusia. Aspek lain yang penting adalah beliefs systems mampu memunculkan kreativitas dan inovasi sumber daya manusia. Dua hal ini yakni kreativitas dan inovasi, sangat penting dimiliki oleh perguruan tinggi di era persaingan yang begitu tajam. Hal ini merupakan core competence perguruan tinggi dalam menyusun perencanaan strategiknya.

\section{Simpulan dan Implikasi}

Metode fenomelogi yang digunakan dalam penelitian ini bertujuan untuk mengungkap bagaimana dosen memaknai sistem pengendalian yang diterapkan. Hasil penelitian menemukan bahwa dosen memaknai sistem pengendalian sebagai sebuah sistem sosial yang ada di Universitas Ciputra. Melalui sistem sosial tersebut, dosen termotivasi untuk bekerja, dengan kata lain melalui sistem tersebut dosen mampu untuk berperilaku sesuai dengan yang diharapkan oleh universitas yaitu melakukan aktivitas yang sesuai dengan apa yang diharapkan oleh program studi yang merupakan faktor penting di universitas.

Penelitian ini berhasil mengungkap bahwa dosen akan termotivasi ketika mereka memaknai beliefs systems sebagai sistem yang mampu untuk mempengaruhi perilaku dosen melalui adanya kualitas hubungan kerja, penghargaan, partisipasi dosen, keteladanan, dan ruang untuk kreativitas dosen. Dua temuan yang menarik adalah berdasarkan pengalaman para dosen mereka merasakan bahwa keteladanan merupakan aspek penting serta adanya ruang untuk menuangkan kreativitas mereka. Temuan yang terakhir dapat menjadi kekhasan di Universitas Ciputra yang berorientasi entrepreneurship, karena fokus tersebut memang mengharuskan staf pengajar untuk memiliki kreativitas. Salah satu aspek penting di Universitas Ciputra agar para dosen termotivasi untuk bekerja dengan optimal dan berperilaku sesuai yang diharapkan oleh universitas adalah diberikannya fasiltas dalam bentuk apapun untuk menemukan, mengembangkan, dan meningkatkan kreativitas.

Penelitian ini memberikan kontribusi yang besar pada literatur sistem pengendalian manajemen, dalam hal ini pengendalian informal yang ternyata mampu untuk mempengaruhi perilaku para dosen di organisasi yang memiliki "entrepreneurial environment". Dalam konteks praktik, maka penelitian ini dapat mendukung dirumuskannya lebih lanjut sistem pengendalian manajemen yang informal dan fokus pada sistem sosial organisasi. Penelitian ini juga membuktikan bahwa melalui metode fenomenologi mampu untuk mengungkap hal yang tidak terungkap dalam hal sistem pengendalian manajemen terutama dari sudut pandang pelaku yang sampai saat ini belum pernah diteliti.

Penelitian ini dapat dikembangkan dengan memperluas subjek penelitian yaitu penelitian di lingkungan Universitas Negeri atau Universitas Swasta Lain yang pengelolaannya tidak berbasis entrepreneurship. Penelitian selanjutnya akan lebih lengkap jika memasukkan informan Ketua Program Studi, Dekan atau bahkan Rektor yang merupakan pengelola sistem pengendalian manajemen. Berikutnya, metode penelitian etnografi dapat juga digunakan untuk mengungkapkan bagaimana peran budaya organisasi dalam hubungannya dengan nilai-nilai organisasi yang tercakup dalam beliefs systems. Melalui metode etnografi yang dilakukan dalam jangka waktu relatif lebih panjang, maka akan dapat diungkapkan lebih dalam mengenai proses munculnya beliefs systems dan bagaimana beliefs systems tersebut mengubah paradigma para informan. Hal ini akan memberikan kontribusi pada pengembangan SPM dari bagaimana munculnya pengendalian informal secara khusus pengendalian yang berasal dari nilai-nilai atau budaya perguruan tinggi.

\section{Daftar Referensi}

Anthony, R. N., \& Govindarajan, V. (2007). Management control system. $12^{\text {th }}$ Edition. New York: McGraw-Hill.

Anthony, R. N., \& Young, D.W. (2003). Management control in nonprotif organization. $7^{\text {th }}$ Edition. New York: McGraw-Hill.

Bruining, H., Bonnet, M., \& Wright, M. (2004). Management control systems and strategy change in buyouts. Management Accounting Research, 15, 155-177.

Chenhall, R. (2003). Management control system design within its organizational context: Findings from contingency-based research and directions for the future. Accounting, Organizations, and Society, 28(2), 127-168.

Creswell, J. W. (2009). Research design: Qualitative, quantitative, and mixed methods approach. $3^{\text {rd }}$ Edition. Los Angeles: SAGE Publication Inc.

Davila, T. (2000). An empirical study on the drivers of management control systems' design in new product development. Accounting, Organizations, and Society, 25, 383-409.

Davila, A., Foster, G., \& Li, M. (2009). Reasons for management control systems adoption: Insights from product development systems choice by early-stage entrepreneurial companies. Accounting, Organizations and Society, 34, 322-334. 
Efferin, S., \& Hopper, T. (2007). Management control, culture and ethnicity in a Chinese Indonesian company. Accounting, Organizations, and Society, 32, 223-262.

Emzir (2010). Metodologi penelitian kualitatif: Analisis data. Jakarta: PT Raja Grafindo Persada.

Ghony, M. D., \& Almanshur, F. (2012) Metodologi penelitian kualitatif. Yogyakarta: Ar-ruzz Media.

Hanna, D. E. (1998). Higher education in an era of digital competition: Emerging organizational models. JALN, 2(1), 66-95.

Henri, J. F. (2006). Management control systems and strategy: A resource-based perspective. Accounting, Organizations and Society, 31, 529-558.

Herbert, I. (2009). Business transformation through empowerment and the implications for management control systems. Journal of Human Resource Costing \& Accounting, 13(3), 221-244.

Hoque, Z., \& Chia. M. (2012) Competitive forces and the levers of control framework in a manufacturing setting a tale of a multinational subsidiary. Qualitative Research in Accounting \& Management, 9(2), 123-145.

Horngren, C., Sundem, G., \& Stratton, W. (2005). Introduction to management accounting. New Jersey: Pearson.

Hycner, R. (1985). Some guidelines for the phenolmenological analysis of interview data. Human Studies, 8, 279-303.

Ismail, T. (2013). Formatting strategy and management control system: evidence from Indonesia. International Journal of Business and Social Science, 4(1), 196-205.

Kahar, A., Triyuwono, I., Irianto, G., \& Ludigdo, U. (2013). Management control systems concept construction of "pangngadereng" based on local wisdom values. Journal of Business and Management, 8(2), 21-30.

Kaplan \& Norton (2004). The strategy map. Boston, MA: Harvard Business School Press.

Kimura, S. \& Mourdoukoutas, P. (2000). Effective integration of management control systems for competing in global industries. European Business Review, 12(1), 41-45.

Kuswarno, E. (2009). Fenomenologi: Metode penelitian komunikasi: Konsepsi, pedoman, dan contoh penelitiannya. Bandung: Widya Padjajaran.

Marginson, S. (2004). Competition and markets in higher education: A 'glocanal' analysis. Policy Futures in Education, 2(2), 175-244.

Merchant, K. A. \& Stedee, W. A. V. (2003). Management control systems: Performance measurement, evaluation, and incentives. New Jersey: Prentice Hall.
Moleong, L. J. (2008). Metode penelitian kualitatif. Bandung: PT Remaja Rosda Karya.

Morsing, M. \& Oswald, D. (2009). Sustainable leadership: Management control systems and organizational culture in novo nordisk a/s. Corporate Governance, 9(1), 83-99.

Ouchi, W. (1979) A conceptual framework for the design of organizational control mechanisms. Management Science, 25(9), 833-848.

Petty, R. \& Guthrie, J. (2000). Intellectual capital literature review: Measurement, reporting and management. Journal of Intellectual Capital, 1(2), 155-176.

Simons, R. (1990). The role of management control systems in creating competitive advantage: new perspective. Accounting, Organization, and Society, 15(1), 127-143.

(1995). Levers of control. Boston: Harvard Business School Press.

Solikhah, B., Rohman, A., \& Meiranto, W. (2010). Implikasi intellectual capital terhadap financial performance, growth dan market value: Studi empiris dengan pendekatan simplistic specification. Simposium Nasional Akuntansi XIII Purwokerto 13-15 Oktober 2010. Purwokerto: Universitas Jenderal Soedirman.

Sudarma, M. (2013). Diktat Penelitian Fenomenologi. Tidak dipublikasikan.

Sugiyono (2012). Memahami penelitian kualitatif. Bandung: Alfabeta.

Tan, H. P., Plowman, D., \& Hancock, P. (2007). Intellectual capital and financial returns of companies. Journal of Intellectual Capital, 8(1), 76-95.

Ulum, I. (2009). Intellectual capital konsep dan kajian empiris. Bandung: Graha Ilmu.

Ulum, I., Ghozali, I., \& Chariri, A. (2008). Intellectual capital dan kinerja keuangan perusahaan: Suatu analisis dengan pendekatan partial least squares. Pontianak: Simposium Nasional Akuntansi XI.

Vosselman, E. \& Kooistra, J. (2009). Accounting for control and trust building in inter firm transactional relationships. Accounting, Organizations, and Society, 34(2), 267-283.

Wahyudi, I. (2008). From physical to accounting control: A study of accounting change resistance. Journal of Accounting \& Organizational Change, 5(2), 228-242.

Wahyuni, S. (2012). Qualitative research method: Theory and practice. Jakarta: Salemba.

Wang, J. (2008). Investigating market value and intellectual capital for S\&P500. Journal of Intellectual Capital, 9(4), 546-563. 
Winston, G. C. (1999). Subsidies, Hierarchy, and Peers: The awkward economics of higher education. The Journal of Economic Perspectives, 13(1), 13-36.

Wongkaew, W. (2013). Management accounting and control systems-unnecessary evils to innovation? Chulalongkorn Business Review, 34(3), 1-21.

Yuniasih, N. W., Wirama, D. G., \& Badera, D. N. (2010). Eksplorasi kinerja pasar perusahaan: kajian berdasarkan modal intelektual (studi empiris pada perusahaan keuangan yang terdaftar di Bursa Efek Indonesia. Simposium Nasional Akuntansi XIII Purwokerto 13-15 Oktober 2010. Purwokerto: Universitas Jenderal Soedirman.

Zhang, J. J., Zhu. N. P., \& Kong, Y. S. (2006). Study on intellectual capital and enterprise's performance: An empirical evidence from the Chinese Securities Market. Journal of Modern Accounting and Auditing, 2(10), 35-39. 